\title{
EFFECTS OF LONG-TERM VACCINATION AGAINST COXIELLA BURNETII ON THE FERTILITY OF HIGH-PRODUCING DAIRY COWS
}

\author{
Irina GARCIA-ISPIERTO, Irene LÓPEZ-HELGUERA, Joan TutuSAUS, Ramón MuR-NovALES \\ and Fernando LÓPEZ-GATIUS* \\ Department of Animal Production, University of Lleida and Agrotecnio Centre, \\ University of Lleida, Avda. Alcalde Rovira Roure 191, 25198 Lleida, Spain
}

(Received 5 October 2014; accepted 17 February 2015)

\begin{abstract}
The impact of long-term vaccination against Coxiella burnetii on the fertility of cows was studied. Double vaccinations three weeks apart at the start of the third trimester of gestation in each of two consecutive pregnancies were applied. The final study population consisted of 410 cows after the first vaccination round. Based on the odds ratios, the likelihood of early fetal loss (pregnancy loss following a positive pregnancy diagnosis before Day 90 of gestation) was higher in control cows $(\mathrm{OR}=1.42)$ than in vaccinated cows. The final study population consisted of 336 cows after the second round of vaccination. According to the odds ratios, vaccinated $C$. burnetii seronegative cows were less likely to be subfertile $(>3 \mathrm{AI})(\mathrm{OR}=0.4)$ compared to non-vaccinated seronegative animals, and the likelihood of early fetal loss was lower in vaccinated C. burnetii seropositive animals $(\mathrm{OR}=0.3)$ compared to non-vaccinated seronegative cows. Seropositivity to $C$. burnetii was positively related to twin pregnancy after the two rounds of vaccination $(\mathrm{OR}=2.1$ and 3.5 , respectively). These results indicate that two consecutive vaccination rounds against $C$. burnetii in advanced gestation reduce subfertility and early fetal loss in dairy cows.
\end{abstract}

Key words: Q fever, subfertility, twin pregnancy, dairy cattle

Since the 1980s, the reproductive performance of high-producing dairy cows has been gradually declining (Lucy, 2001; López-Gatius, 2003). Several genes with lethal effect on embryos were identified in Holstein cattle with a rather high gene frequency (VanRaden et al., 2011), which could partly explain this decline. Numerous factors besides high milk production, such as heat stress, bull or inseminator, are responsible for the loss of fertility in dairy cows (LópezGatius, 2012, 2013). Although these factors and some infectious diseases like brucellosis and neosporosis are far better controlled in modern dairy farms, other diseases spread worldwide, such as Coxiella burnetii infection, are not yet well understood, poorly diagnosed and treated.

\footnotetext{
"Corresponding author; E-mail: flopez@prodan.udl.cat; Phone: 0034 (973) 702-563
} 
Coxiella burnetii is an obligate intracellular bacterium and the aetiological agent of Q fever, a re-emerging zoonosis worldwide. Domestic ruminants are the main reservoir and source of infection for humans (Maurin and Raoult, 1999; Arricau-Bouvery and Rodolakis, 2005). Infection mainly occurs via aerosol inhalation, but transmission may also occur by ingestion of contaminated material (Angelakis and Raoult, 2010). Although the symptoms of Q fever are well known in humans and small ruminants, the pathogenesis of this disease in cattle remains unclear (Agerholm, 2013). Clinical signs in cattle have not been well characterised and some are disputed, especially those affecting reproduction (Garcia-Ispierto et al., 2014). Moreover, the existence of seronegative shedders and seropositive non-shedders determines a need for both serological and molecular biology techniques for a proper laboratory diagnosis (Guatteo et al., 2007). Determining the $C$. burnetii infection status of all cows is an unaffordable task (Garcia-Ispierto et al., 2014). Thus, control measures need to be applied blindly without diagnosing individual cases of infection.

The effects of $C$. burnetii on cattle reproduction are partly hypothetical, therefore the rationale of the vaccination may be to prevent a theoretical negative impact. While such effects of $C$. burnetii infection may be difficult to prove due to their multifactorial pathogenesis, a vaccine against the bacterium may be used to show a possible reduction of severity of reproductive disorders following vaccination. Although vaccination has been widely recommended for small ruminants (Arricau-Bouvery et al., 2005; Astobiza et al., 2011), few studies were performed in cattle.

Vaccination against $C$. burnetii has been proposed to control and reduce bacterial shedding in dairy cattle (Guatteo et al., 2008; Taurel et al., 2012). More recently, two studies have examined the benefits of vaccination during late gestation (López-Helguera et al., 2013; Tutusaus et al., 2013). Vaccination proved to be safe, did not increase the abortion rate, and was related to an improvement of the subsequent fertility of the herds, especially when used in C. burnetii seronegative animals. In order to reinforce and expand previous results, the present study was designed to investigate the impacts of a double vaccination protocol (two rounds of vaccination given during late gestation, Days 171-177, in two consecutive pregnancies) on the fertility of high-producing dairy cows in a single Coxiella-infected herd. To the best of our knowledge, a long-term vaccination programme has not yet been tested in cattle.

\section{Materials and methods}

\section{Cattle and herd management}

The study was performed from February 2011 to August 2013 in a single commercial Holstein-Friesian dairy herd in north-eastern Spain comprising 750 
cows. The herd was known to be persistently infected with Coxiella burnetii according to tests conducted between 2010 and 2011 (Garcia-Ispierto et al., 2010; Garcia Ispierto et al., 2011; López-Gatius et al., 2012; Tutusaus et al., 2013). These included individual ELISA determinations of antibodies against $C$. burnetii (more than 30\% seropositive animals older than 12 months) and polymerase chain reaction (PCR) tests on bulk tank milk samples to detect the presence of $C$. burnetii DNA (more than $10^{4}$ bacteria $/ \mathrm{mL}$ ).

Mean annual milk production for the study period was $11,940 \mathrm{~kg}$. All animals were tuberculosis and brucellosis free. Vaccination programmes for the prevention of bovine viral diarrhoea (BVD) and infectious bovine rhinotracheitis (IBR) included modified live vaccines (Cattlemaster, Pfizer, New York, USA) for animals 6-8 months old. Lactating animals received killed vaccines at dry-off (Triangle 4, Boehringer Ingelheim, Barcelona, Spain). All animals included in this study had been vaccinated against these infections when they were younger.

All cows were artificially inseminated. Oestrus was confirmed by palpation per rectum (López-Gatius and Camón-Urgel, 1991; López-Gatius, 2000). If cows returned to oestrus, their status was confirmed by examination per rectum, and the animals were recorded as non-pregnant. In the remaining cows, pregnancy diagnosis was performed by ultrasound 28-34 days post-insemination. Pregnancy was confirmed by ultrasound 20 days later and by palpation per rectum 90-96 and 180-186 days post-insemination. Cows diagnosed as non-pregnant were either returned to the reproductive programme or scheduled for culling. Since management and cow-related non-infectious factors are extensively linked to late embryonic or early fetal loss in our geographical area (López-Gatius and Garcia-Ispierto, 2010; López-Gatius et al., 2013), early fetal loss was recorded when the diagnosis on days 90-96 proved negative.

\section{Experimental design}

At the study outset, individual blood tests were performed in heifers (more than 12 months old) and cows to determine the C. burnetii antibody status of the herd. According to their serological status, 420 animals ( 96 heifers and 324 cows) were randomly assigned to a control $(\mathrm{n}=208 ; 60$ seropositive and 148 seronegative) or vaccinated ( $\mathrm{n}=212 ; 62$ seropositive and 150 seronegative) group. Heifers and cows in the vaccinated group received two subcutaneous doses three weeks apart of an inactivated vaccine against $C$. burnetii (Coxevac, CEVA Santé Animale, Libourne, France) on Days 171-177 and 192-198 of gestation. Each 4-mL vaccine dose contained purified phase I C. burnetii corpuscular antigens $(100 \mu \mathrm{g} / \mathrm{mL})$ inactivated with formaldehyde. Animals that aborted before parturition (10/420: six control and four vaccinated cows) were excluded from the study. After the first parturition, pregnant cows were vaccinated a second time following the same protocol described above on Days 171-177 and 192-198 of the second gestation in the study. All control animals used in the first vaccination 
round remained as controls in the second round, while all vaccinated animals were vaccinated again during the second pregnancy. The reproductive variables examined were those recorded after the first vaccination round and first parturition and after the second vaccination round and second parturition. The final study population after the first parturition comprised 410 cows, 102 of which were seropositive for $C$. burnetii $(24.9 \%)$. The final study population after the second parturition comprised 336 cows, 85 of which were seropositive for $C$. burnetii $(25.3 \%)$.

Vaccine application was performed by the authors so that this study was done blinded for the herd manager. At the end of the study, pregnant seronegative cows in the control group $(\mathrm{n}=116)$ were screened again for Coxiella seropositivity. The seroconversion rate was zero.

\section{Coxiella burnetii antibodies}

Serum was obtained from each blood sample and kept at $4{ }^{\circ} \mathrm{C}$ until analysis performed within $48 \mathrm{~h}$ of collection. A commercial indirect ELISA LSI VET RUMINANT Milk/Serum Q FEVER kit (CoxLS kit, Laboratoire Service International, Lissieu, France) was used to determine antibodies against $C$. burnetii in the serum samples. The test was carried out according to the manufacturer's instructions. Test sensitivity and specificity are $100 \%$ and $95 \%$, respectively (García-Pérez et al., 2009). The antigen used with the ELISA CoxLS kit was isolated from domestic ruminants at INRA, Nouzilly (France). A cocktail of both antigen phases (I and II) was used in this assay to detect total anti-C. burnetii immunoglobulin $\mathrm{G}$ antibodies (IgG) (Guatteo et al., 2008). Results are expressed as $\mathrm{S} / \mathrm{P}$ ratio $\left(\mathrm{S} / \mathrm{P}\right.$ ratio $\left.=\mathrm{OD}_{\text {Sample }} / \mathrm{OD}_{\text {Pos Control }} \times 100\right)$. A serum sample was scored negative for antibodies against Coxiella when the S/P ratio was lower than 40 .

\section{Data collection and statistical analysis}

In the geographical region of north-eastern Spain, only two seasons, i.e. warm (May to September) and cool (October to April) can be clearly distinguished (Labèrnia et al., 1998; Garcia-Ispierto et al., 2007). Parturition and AI dates were used to analyse the effects of season on fertility variables.

The following data were recorded for each animal: parity (1st vs. 2nd or more parity, after the first parturition of the study; or 2nd vs. 3rd or more parity, after the second parturition), treatment group (control vs. vaccine), C. burnetii serological status, twinning, stillbirth, retained placenta, season of parturition and AI (cool vs. warm), milk production at AI (average for the month of AI), inseminating bull, inseminator, culling before Day 150 in milk, pregnancy diagnosis 28-34 days following AI, subfertility (cows undergoing more than three AI within the first 150 days in milk), twin pregnancy (single vs. twin/multiple) and early fetal loss (pregnancy loss following a positive pregnancy diagnosis during 
the first 90 days of gestation). Parity ( 1 vs. $2+$ or 2 vs. $3+)$, twinning, retained placenta, stillbirth, season of parturition, early fetal loss, Coxiella serological status and treatment group and AI ( $\leq 3$ vs. $>3$ ) were considered dichotomous variables (which can have two values only). The inseminator and the semenproviding bull were categorical variables, while milk production at AI (continuous variable) was considered a factor in the analyses.

Logistic regression analysis was performed on data from each cow, using stillbirth, retained placenta, culling within the first 150 days in milk, pregnancy at first $\mathrm{AI}$ and subfertility, twin pregnancy and early fetal loss as the dependent variable (0 or 1$)$, and the variables described above as independent factors. Regression analyses were conducted according to the method of Hosmer and Lemeshow (1989) through the logistic procedure of the SPSS package (SPSS software version 18.0, SPSS Inc., Chicago, IL, USA).

\section{Results}

\section{After the first vaccination round and first parturition}

Mean ( \pm SD) milk production at AI was $43.2 \pm 5.6(24-66) \mathrm{kg}$ and the mean parity was $1.9 \pm 1.6(1-10)$. The parturition-first insemination interval for the study period was $68.7 \pm 9.6$ (45-91) days.

The study population for each dependent variable comprised either 410 cows (dependent variables: stillbirth, retained placenta, culling within the first 150 days in milk), 389 cows (dependent variable: conception rate to first $\mathrm{AI}$ ) or 378 cows (dependent variable: subfertility before Day 150 in milk). Three hundred and seventy-three cows became pregnant before Day 150 in milk. The twin pregnancy and early fetal loss rates in these cows were $13.9 \%$ and $11.3 \%$, respectively.

No factor could be related to stillbirth $(n=29)$, retained placenta $(n=37)$ or culling before Day 150 in milk $(n=69)$. Plausible interactions such as season and parity/retained placenta were not detected.

Conception rates at first AI were 36.2\% (71/196) and 35.8\% (69/193) for the control and vaccinated groups, respectively. Subfertile rates were $16.8 \%$ (32/190) and 13.8\% (26/188) for the control and vaccinated groups, respectively. According to the odds ratios, multiparous cows (2nd or more parity) were more likely to be subfertile than primiparous animals $(\mathrm{OR}=1.4 ; 1.1-4.6$ at $95 \%$ confidence interval; $\mathrm{P}=0.03$ ).

Based on the odds ratios, the likelihood of twin pregnancy was higher (22.2\%: 20/90) in C. burnetii seropositive cows (OR $=2.1 ; 1.2-4.6$ at $95 \%$ confidence interval; $\mathrm{P}=0.03)$ than in seronegative cows $(11.3 \%: 32 / 283)$. The likelihood of early fetal loss was higher in cows carrying twins $(\mathrm{OR}=2)$ and in con- 
trol cows $(\mathrm{OR}=1.42)$ than in cows carrying singletons and vaccinated cows, respectively (Table 1).

\section{Table 1}

Odds ratios of the variables included in the final logistic regression model for factors affecting early fetal loss after the first round of vaccination $(n=373)$

\begin{tabular}{llccccc}
\hline Factor & \multicolumn{1}{c}{ Class } & $\mathrm{n}$ & $\begin{array}{c}\text { Early fetal } \\
\text { loss, } \%\end{array}$ & Odds ratio & $\begin{array}{c}95 \% \text { confidence } \\
\text { interval }\end{array}$ & P \\
\hline Vaccine & Treatment & $16 / 135$ & 11.9 & Reference & & \\
& Control & $26 / 137$ & 19 & 1.42 & $1.1-2.8$ & 0.04 \\
Presence of twins & Singletons & $29 / 321$ & 9 & Reference & & \\
& Twins & $13 / 52$ & 25 & 2 & $1.2-4.6$ & 0.03 \\
\hline
\end{tabular}

Likelihood ratio test $=255.4 ; 4 \mathrm{df}, \mathrm{P}=0.0001$

\section{After the second vaccination round and second parturition}

Mean ( \pm SD) milk production at AI was $46.4 \pm 8.5(28-72) \mathrm{kg}$ and the mean parity was $2.6 \pm 1.4(1-11)$. The parturition-first insemination interval for the study period was $65.7 \pm 10.7$ (45-85) days.

The study population for each dependent variable comprised either 336 cows (dependent variables: stillbirth, retained placenta, culling within the first 150 days in milk), 313 cows (dependent variable: conception rate to first $\mathrm{AI}$ ) or 295 cows (dependent variable: subfertility before Day 150 in milk). Two hundred and eighty cows became pregnant before Day 150 in milk. The twin pregnancy and early fetal loss rates in these cows were $22.1 \%$ and $24.3 \%$, respectively.

No factor could be related to stillbirth $(\mathrm{n}=19)$, retained placenta $(\mathrm{n}=28)$ or culling before Day 150 in milk $(n=41)$. Plausible interactions such as season and parity/retained placenta were not detected.

Conception rates at first AI were $33.3 \%$ (52/156) and 34.4\% (54/157) for the control and vaccinated groups, respectively. According to the odds ratios, vaccinated $C$. burnetii seronegative cows were less likely to be subfertile (OR = 0.4) than non-vaccinated seronegative animals. Moreover, cows that delivered during the warm period were more likely to be subfertile than the remaining animals $(\mathrm{OR}=2.0)$ (Table 2).

According to the odds ratios, the likelihood of twin pregnancy was higher (33.9\%: 21/62) in C. burnetii seropositive cows (OR $=3.5 ; 1.6-7.6$ at $95 \%$ confidence interval; $\mathrm{P}=0.02)$ than in seronegative cows $(18.8 \%$ : $41 / 218)$. The likelihood of early fetal loss was lower in vaccinated $C$. burnetii seropositive cows $(\mathrm{OR}=0.3)$ than in the remaining animals (Table 3$)$. 
Table 2

Odds ratios of the variables included in the final logistic regression model for factors affecting subfertility $(>3 \mathrm{AI})$ after the second round of vaccination $(n=295)$

\begin{tabular}{|c|c|c|c|c|c|c|}
\hline Factor & Class & $\mathrm{n}$ & $\begin{array}{l}\text { Subfertile } \\
\text { cows, } \%\end{array}$ & Odds ratio & $\begin{array}{c}95 \% \text { confidence } \\
\text { interval }\end{array}$ & $\mathrm{P}$ \\
\hline \multicolumn{7}{|c|}{ C. burnetii serology $\times$ vaccination } \\
\hline & Negative $\times \mathrm{C}$ & $34 / 121$ & 28.1 & Reference & & \\
\hline & Negative $\times \mathrm{V}$ & $16 / 112$ & 14.3 & 0.4 & $0.2-0.8$ & 0.01 \\
\hline & Positive $\times \mathrm{C}$ & $5 / 25$ & 20.0 & 0.8 & $0.2-3.1$ & 0.6 \\
\hline & Positive $\times \mathrm{V}$ & $12 / 37$ & 32.4 & 1.2 & $0.3-3.2$ & 0.4 \\
\hline \multicolumn{7}{|c|}{ Season of parturition } \\
\hline & Cool & $24 / 176$ & 13.6 & Reference & & \\
\hline & Warm & $43 / 119$ & 36.1 & 2.0 & $1.2-4.4$ & $<0.001$ \\
\hline
\end{tabular}

Likelihood ratio test $=245.62 ; 71 \mathrm{df}, \mathrm{P}=0.0001 ; \mathrm{C}$ : control group, $\mathrm{V}$ : vaccinated group

Table 3

Odds ratios of the variables included in the final logistic regression model for factors affecting early fetal loss (before Day 90 of pregnancy) after the second round of vaccination $(n=280)$

\begin{tabular}{|c|c|c|c|c|c|c|}
\hline Factor & Class & $\mathrm{n}$ & $\begin{array}{l}\text { Subfertile } \\
\text { cows, } \%\end{array}$ & Odds ratio & $\begin{array}{l}95 \% \text { confidence } \\
\text { interval }\end{array}$ & $\mathrm{P}$ \\
\hline \multicolumn{7}{|c|}{ C. burnetii serology $\times$ vaccination } \\
\hline & Positive $\times \mathrm{V}$ & $4 / 37$ & 10.8 & Reference & & \\
\hline & Negative $\times \mathrm{V}$ & $24 / 102$ & 23.5 & 1.2 & $1.1-2.1$ & 0.04 \\
\hline & Positive $\times \mathrm{C}$ & $8 / 25$ & 32.0 & 1.2 & $1.1-3.3$ & 0.04 \\
\hline & Negative $\times \mathrm{C}$ & $32 / 116$ & 27.6 & 3.2 & $1.1-4.2$ & 0.03 \\
\hline
\end{tabular}

Likelihood ratio test $=230.45 ; 65 \mathrm{df}, \mathrm{P}=0.0001$; : control group, $\mathrm{V}$ : vaccinated group

\section{Discussion}

The current work is the first study investigating the effects of long-term vaccinations against $C$. burnetii given during late pregnancy on the subsequent fertility of high-producing dairy cows. The findings indicate that vaccinated seronegative animals were less likely to be subfertile and vaccinated seropositive animals were less likely to lose their pregnancy than the non-vaccinated herd mates. Nevertheless, vaccination did not improve the conception rate. Surprisingly, the cows seropositive for C. burnetii (regardless of their vaccination status) showed a higher twin pregnancy rate than seronegative animals.

Although twin pregnancy has been strongly related to previous twinning and the parity number (Andreu-Vázquez et al., 2012), the only factor affecting 
the twin pregnancy rate was the seropositivity against $C$. burnetii. A further regression analysis was performed for each vaccine round changing the variable parity (1st vs. 2nd or more parity for data after the first vaccine round, or 2 nd vs. 3rd or more parity, for data after the second vaccine round - dichotomous) to lactation number (categorical variable), and the result was the same (data not shown).

Vaccination against $C$. burnetii seems to be the only effective way to control Q fever in a herd. Although this measure has been demonstrated to be efficient for small ruminants (Arricau-Bouvery et al., 2005; Astobiza et al., 2011), in cattle some questions still remain unclear. For example, when used in infected animals during the insemination period, vaccination does not prevent $C$. burnetii shedding (Guatteo et al., 2008; Rousset et al., 2009), questioning vaccination in adults. Notwithstanding, when cows in a recent study were vaccinated at the start of the third trimester of gestation, this measure proved safe and was related to an improvement of the subsequent fertility of the herd, especially when used in seronegative animals (López-Helguera et al., 2013), despite the fact that vaccination during this period did not reduce shedding after parturition (Tutusaus et al., 2014). In the present study, two consecutive rounds of vaccines during late pregnancy reduced the proportion of subfertile cows among seronegative animals after the second round of vaccination, reinforcing previous results supporting the benefits of vaccinating seronegative cows (López-Helguera et al., 2013). It is therefore likely that controlled exposure to the infectious agent by vaccination protects susceptible seronegative animals from clinical symptoms or subclinical lesions and thus improves fertility. Possible positive effects of vaccination on subfertile cows after the first round of vaccination could be masked by primiparous cows which are more fertile than cows in their second or more parity (López-Gatius, 2012). The percentages of subfertile cows were 15.3\% (58/378) and $22.7 \%(67 / 295)$ for the first and the second round of vaccination, respectively. Animals receiving the first round of vaccination were logically younger and their results not comparable to those obtained from their subsequent parity.

In the same sense, the $11.3 \%$ early fetal loss found after the first vaccination round cannot be compared to the early fetal loss rate of $24.3 \%$ obtained after the second vaccination round, in which cows were older. Primiparous cows have a lower risk for twin pregnancy and thus for pregnancy loss than their multiparous partners (Andreu-Vázquez et al., 2012). In fact, the effect of vaccination in reducing early fetal loss after the first round of vaccination could be clarified after the second vaccination round. The second vaccination reduced significantly the losses of only vaccinated seropositive cows. What is more difficult to explain is why fewer seropositive vaccinated animals suffered early fetal loss compared to seronegative vaccinated cows. The presence of twins has been described as the main factor related to pregnancy loss during the early fetal period in highproducing dairy cows (López-Gatius and Garcia-Ispierto, 2010; López-Gatius et 
al., 2013). If $C$. burnetii manages to increase the twinning rate in infected animals, and the vaccination of these animals lowers their risk of early fetal loss, perhaps the vaccine is able to prevent twin pregnancies in infected animals. Whether this hypothesis is true or not, certain effects of the bacterium on the cow could explain some controversial issues. For example, it has been reported that seropositive shedders get pregnant before seronegative cows (López-Gatius et al., 2012; Garcia-Ispierto et al., 2013). These animals could have higher double ovulation rates, making them more fertile (Garcia-Ispierto et al., 2012). Thus, in cows exposed to C. burnetii, impaired dominant follicle selection could lead to the selection of more than one dominant follicle and this might promote double ovulation. Hence, infected/vaccinated animals are probably protected against the detrimental effects of a new infection or even against recrudescence of the bacterium during their fertile period (Garcia-Ispierto et al., 2014) and this might promote double ovulation. In effect, cow wellbeing has been related to a greater chance of double ovulation (López-Gatius et al., 2005). The effects of vaccination on the rates of both double ovulation and twin pregnancy require further investigation.

In a previously reported study of the first parturition in two dairy herds (López-Helguera et al., 2013), cows in the vaccinated group were 1.22 times more likely to conceive during the first 150 days in milk than those in the control group. In the current study, cows were vaccinated again (or remained as control), and fertility was examined after the first and second parturition. Using logistic regression, vaccinated (previously seronegative) cows were less likely to be subfertile, although the conception rate was not improved. Fertility variables for dairy herds are subject to multiple factors and vary between herds. Probably factors such as season and parity could mask the possible positive effect of vaccination on conception rate during the first 150 days in milk in the single herd involved in this study.

Seronegative control cows remained seronegative at the end of the study, in agreement with previous studies in which the change of serological status in any way (i.e. from seronegative to seropositive or from seropositive to seronegative) was not a common event in dairy cattle (Guatteo et al., 2007; GarciaIspierto et al., 2011).

In conclusion, our results indicate that it is possible to reduce subfertility and early fetal loss in dairy cows by subjecting them to two consecutive vaccination rounds against $C$. burnetii during advanced gestation.

\section{Acknowledgements}

The authors thank Ana Burton for assistance with the English translation. Joan Tutusaus was supported by a grant from the University of Lleida and Ramón MurNovales by an FPI grant from the Spanish Ministry of Science and Innovation, MICINN, BES-2013-063215. 


\section{References}

Agerholm, J. S. (2013): Coxiella burnetii associated reproductive disorders in domestic animals: a critical review. Acta Vet. Scand. 55, 13.

Andreu-Vázquez, C., Garcia-Ispierto, I. and López-Gatius, F. (2012): Photoperiod length and the estrus synchronization protocol used before $\mathrm{AI}$ affect the twin pregnancy rate in dairy cattle. Theriogenology 78, 1209-1216.

Angelakis, E. and Raoult, D. (2010): Q Fever. Vet. Microbiol. 140, 297-309.

Arricau-Bouvery, N. and Rodolakis, A. (2005): Is Q fever an emerging or re-emerging zoonosis? Microbiol. Immunol. 39, 663-671.

Arricau-Bouvery, N., Souriau, A., Bodier, C., Dufour, P., Rousset, E. and Rodolakis, A. (2005): Effect of vaccination with phase I and phase II Coxiella burnetii vaccines in pregnant goats. Vaccine 23, 4392-4402.

Astobiza, I., Barandika, J. F., Ruiz-Fons, F., Hurtado, A., Povedano, I., Juste, R. A. and GarcíaPérez, A. L. (2011): Four-year evaluation of the effect of vaccination against Coxiella burnetii on reduction of animal infection and environmental contamination in a naturally infected dairy sheep flock. Appl. Environ. Microbiol. 77, 7405-7407.

Garcia-Ispierto, I., Almería, S. and López-Gatius, F. (2011): Coxiella burnetii seropositivity is highly stable throughout gestation in lactating high-producing dairy cows. Reprod. Domest. Anim. 46, 1067-1072.

García-Ispierto, I., López-Gatius, F., Bech-Sabat, G., Santolaria, P., Yániz, J. L., Nogareda, C., De Rensis, F. and López-Béjar, M. (2007): Climate factors affecting conception rate of high producing dairy cows in northeastern Spain. Theriogenology 67, 1379-1385.

Garcia-Ispierto, I., López-Helguera, I., Martino, A. and López-Gatius, F. (2012): Reproductive performance of anoestrous high-producing dairy cows improved by adding equine chorionic gonadotrophin to a progesterone-based oestrous synchronizing protocol. Reprod. Domest. Anim. 47, 752-758.

Garcia-Ispierto, I., López-Helguera, I., Tutusaus, J., Serrano, B., Monleón, E., Badiola, J. J. and López-Gatius, F. (2013): Coxiella burnetii shedding during the peripartum period and subsequent fertility in dairy cattle. Reprod. Domest. Anim. 48, 441-446.

García-Ispierto, I., Nogareda, C., Yániz, J. L., Almería, S., Martínez-Bello, D., de Sousa, N. M., Beckers, J. F. and López-Gatius, F. (2010): Neospora caninum and Coxiella burnetii seropositivity are related to endocrine pattern changes during gestation in lactating dairy cows. Theriogenology 74, 212-220.

Garcia-Ispierto, I., Tutusaus, J. and López-Gatius, F. (2014): Does Coxiella burnetii affect reproduction in cattle? A clinical update. Reprod. Domest. Anim. 49, 529-535.

García-Pérez, A. L., Astobiza, I., Barandika, J. F., Atxaerandio, R., Hurtado, A. and Juste, R. A. (2009): Short communication: investigation of Coxiella burnetii occurrence in dairy sheep flocks by bulk-tank milk analysis and antibody level determination. J. Dairy Sci. 92, 1581-1584.

Guatteo, R., Beaudeau, F., Joly, A. and Seegers, H. (2007): Coxiella burnetii shedding by dairy cows. Vet. Res. 38, 849-860.

Guatteo, R., Seegers, H., Joly, A. and Beaudeau, F. (2008): Prevention of Coxiella burnetii shedding in infected dairy herds using a phase I C. burnetii inactivated vaccine. Vaccine 26, $4320-4328$.

Hosmer, D. W. and Lemeshow, S. (1989): Applied Logistic Regression. Wiley, New York, USA.

Labèrnia, J., López-Gatius, F., Santolaria, P., Hanzen, C., Laurent, Y. and Houtain, J. Y. (1998): Influence of calving season on the interactions among reproductive disorders of dairy cows. Anim. Sci. 67, 387-393.

López-Gatius, F. (2000): Site of semen deposition in cattle: a review. Theriogenology 53, 1407-1414.

López-Gatius, F. (2003): Is fertility declining in dairy cattle? A retrospective study in northeastern Spain. Theriogenology 60, 89-99. 
López-Gatius, F. (2012): Factors of a noninfectious nature affecting fertility after artificial insemination in lactating dairy cows. A review. Theriogenology 77, 1029-1041.

López-Gatius, F. (2013): Approaches to increase reproductive efficiency in artificially inseminated dairy cows. Anim. Reprod. 10, 143-147.

López-Gatius, F. and Camón-Urgel, J. (1991): Confirmation of estrus rates by palpation per rectum of genital organs in normal repeat dairy cows. J. Vet. Med. A 38, 553-556.

López-Gatius, F. and García-Ispierto, I. (2010): Ultrasound and endocrine findings that help to assess the risk of late embryo/early foetal loss by non-infectious cause in dairy cattle. Reprod. Domest. Anim. 45 (Suppl. 3), 15-24.

López-Gatius, F., Almeria, S. and Garcia-Ispierto, I. (2012): Serological screening for Coxiella burnetii infection and related reproductive performance in high producing dairy cows. Res. Vet. Sci. 93, 67-73.

López-Gatius, F., Almería, S., Serrano-Pérez, B. and Garcia-Ispierto, I. (2013): Managing gestation in cattle. Anim. Reprod. 10, 252-257.

López-Gatius, F., López-Béjar, M., Fenech, M. and Hunter, R. H. F. (2005): Ovulation failure and double ovulation in dairy cattle: risk factors and effects. Theriogenology 63, 1298-1307.

López-Helguera, I., López-Gatius, F., Tutusaus, J. and Garcia-Ispierto, I. (2013): Reproductive performance of high producing lactating cows in Coxiella-infected herds following vaccination with phase-I Coxiella burnetii vaccine during advanced pregnancy. Vaccine 31, 3046-3050.

Lucy, M. C. (2001): Reproductive loss in high-producing dairy cattle: where will it end? J. Dairy Sci. 84, 1277-1293.

Maurin, M. and Raoult, D. (1999): Q fever. Clin. Microbiol. Rev. 12, 518-553.

Rousset, E., Durand, B., Champion, J. L., Prigent, M., Dufour, P., Forfait, C., Marois, M., Gasnier, T., Duquesne, V., Thiéry, R. and Aubert, M. F. (2009): Efficiency of a phase 1 vaccine for the reduction of vaginal Coxiella burnetii shedding in a clinically affected goat herd. Clin. Microbiol. Infect. 15, 188-189.

Taurel, A. F., Guatteo, R., Joly, A. and Beaudeau, F. (2012): Effectiveness of vaccination and antibiotics to control Coxiella burnetii shedding around calving in dairy cows. Vet. Microbiol. 159, $432-437$.

Tutusaus, J., López-Gatius, F., Almería, S., Serrano, B., Monleón, E., Badiola, J. J. and GarcíaIspierto, I. (2013): No detectable precolostral antibody response in calves born from cows with cotyledons positive for Coxiella burnetii by quantitative PCR. Acta Vet. Hung. 61, 432-441.

Tutusaus, J., López-Gatius, F., Serrano, B., Monleón, E., Badiola, J. J. and Garcia-Ispierto, I. (2014): Serological and shedding patterns after Coxiella burnetii vaccination in the third gestation trimester in dairy cows. Acta Vet. Hung. 62, 145-154.

VanRaden, P. M., Olson, K. M., Null, D. J. and Hutchison, J. L. (2011): Harmful recessive effects on fertility detected by absence of homozygous haplotypes. J. Dairy Sci. 94, 6153-6161. 